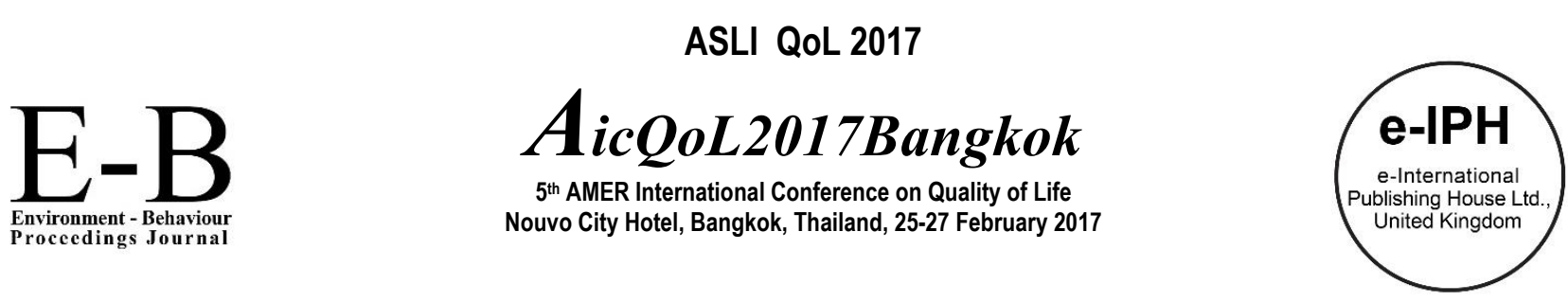

\title{
Relationship between Types of Organization with the Quality of Soft-scape Construction Work in Malaysia
}

\author{
Jasasikin Ab Sani ${ }^{1 *}$, Nur Athirah Ahmad Sharip ${ }^{2}$, Noriah Othman ${ }^{3}$, Mohd Ramzi Mohd Hussain ${ }^{4}$ \\ 1 Kulliyyah of Architecture and Environmental Design, International Islamic University Malaysia, Jalan Gombak, 53100 Kuala Lumpur, Malaysia \\ 2 Kulliyyah of Architecture and Environmental Design, International Islamic University Malaysia, Jalan Gombak, 53100 Kuala Lumpur, Malaysia \\ 3 Faculty of Architecture, Planning and Surveying MARA University of Technology, Shah Alam, 40450, Selangor, Malaysia \\ 4 Kulliyyah of Architecture and Environmental Design, International Islamic University Malaysia, Jalan Gombak, 53100 Kuala Lumpur, Malaysia
}

\begin{abstract}
This paper intends to focus on the relationship between types of organisations with the issues of quality of soft-scape construction work. The types of organizations are consultant, contractor, developer, government agency, and educational institution. This research will be using the mix method approach. Chi-square analysis was also performed to find the significant level of relationship between the respondents. Respondents of the survey are among Landscape Architects listed in ILAM directory. The study managed to conduct the questionnaire on 225 persons. This paper was identified the significant difference of the respondents from different type of organisations with the issues of soft-scape construction quality.
\end{abstract}

Keywords: Quality Standard; Soft-scape Construction; Organization.

ISSN: 2398-4287@ 2017. The Authors. Published for AMER ABRA by e-International Publishing House, Ltd., UK. This is an open access article under the CC BYNC-ND license (http://creativecommons.org/licenses/by-nc-nd/4.0). Peer-review under responsibility of AMER (Association of Malaysian Environment-Behaviour Researchers), ABRA (Association of Behavioural Researchers on Asians) and CE-Bs (Centre for Environment-Behaviour Studies), Faculty of Architecture, Planning \& Surveying, Universiti Teknologi MARA, Malaysia.

\subsection{Introduction}

Take aspiration from the Malaysian Government to transform Malaysia into a garden nation by 2020 by the Malaysian government in 2006. Therefore, plant plays an important part in the greening of Malaysia cities. The landscape industry has grown quite significantly after the vision towards the most Beautiful Garden Nation. Establishment of the National Landscape Department (NLD) under Ministry of Housing And Local Government was officially set up on 1st January 1996 has shown a serious commitment of Malaysian government on ensuring quality landscape development in the country. Quality standard plays a significant role in the construction industry. Landscape construction can be part of an overall construction project or independent landscape project. However, quality of implementation related landscape project always an issue that requires duly attention. Therefore the objective of quality standard in landscape construction may not be different from the purpose of quality standard in overall construction. Landscape Standard has established in Malaysia is MS 2603:2015 landscape planting materials-trees-specification. Therefore, another document related to quality control of landscape project was referred to the process of achieving the objectives of the research. Experts from the different organisation related to the quality of soft-scape construction will involve coming out with the firm result.

\subsection{Quality standard in Landscape Architecture}

Landscape construction can be part of an overall construction project or independent landscape project. Therefore the objective of quality standard in landscape construction may not be different from the objective of quality standard in overall construction. Landscape construction requires knowledge of a broad range of construction techniques (Sauter, 2011). Hazreena et al. (2013) have

\footnotetext{
* Jasasikin Ab Sani. Tel.: +6-016-674-3806

E-mail address: jasasikin@iium.edu.my
}

ISSN: 2398-4287@ 2017. The Authors. Published for AMER ABRA by e-International Publishing House, Ltd., UK. This is an open access article under the CC BYNC-ND license (http://creativecommons.org/licenses/by-nc-nd/4.0/). Peer-review under responsibility of AMER (Association of Malaysian Environment-Behaviour Researchers), ABRA (Association of Behavioural Researchers on Asians) and CE-Bs (Centre for Environment-Behaviour Studies), Faculty of Architecture, Planning \& Surveying, Universiti Teknologi MARA, Malaysia.

DOI: http://dx.doi.org/10.21834/e-bpj.v2i5.685 
listed in details the scopes of landscape construction in their study on landscape construction course in landscape architectural program. In the previous study, Rogers (1996) explained that Landscape Architecture is a profession that applies artistic and scientific principles to the research, planning, designing and management of both natural and built environment.

Landscape construction in total comprises two major areas i.e. hard-scape and soft-scape. David W. (2013) stated that Soft-scape includes the animate, horticultural elements of landscape design, i.e., plants. Soft-scape work can be referred as part of landscape work related to the activities of introducing or preserving horticultural elements i.e. soil and vegetation/plants and any other components related to the work.

Establishment of the National Landscape Department (NLD) under Ministry of Housing And Local Government was officially set up on 1st January 1996 has shown a serious commitment of Malaysian government on ensuring quality landscape development in the country. Since then, the department was entrusted with the responsibilities of landscaping and greening the whole country. Based on the approval by Economic Planning Unit (EPU), the National Landscape Department set the pace to provide services in monitoring and establishing national landscape development for the nation (NLD, 2009)

In 2008, NLD established a National Landscape Guideline second edition which is the refined edition of the first National Landscape Guideline established by Landscape Unit under Jabatan Perancangan Bandar dan Desa in 1995 (NLD, 2009). National Landscape Department (NLD) in Garis Panduan Landskap Negara 2 (GLPN 2)(2008) defines a plant as trees, palms, shrubs, ground covers, and plants of other descriptions to be provided by the Contractor, as shown in the Drawings or listed in the plant schedules.

The guidelines cover all areas of landscape construction to be used as a reference for implementation of landscape project under the Government of Malaysia. Guideline for soft landscape is stipulated under section 4. The guideline consists of ten (10) sub-sections related to implementation of soft landscape construction as follows:

i. The method of plant selection

ii. Transportation of plant to site

iii. Preparation of site nursery

iv. Site clearance

v. Preparation of soil mixture

vi. Preparation of planting hole

vii. Planting method

viii. Staking

ix. $\quad$ Mulching

x. Treatment method of planting hole

The National Landscape guideline has been used as a standard landscape specification in Contract Document for landscape project under jurisdiction of NLD since its establishment.

To further enhance the mechanism of landscape development quality control, NLD on the year of 2011 has established National Landscape Policy. In conjunction with the establishment of policy, Deputy Prime Minister of Malaysia, Tan Sri Dato' Muhyuddin Mohd Yassin in his message highlighted that in the efforts to chart the development towards a high income nation, quality landscape development and landscape natural resources protection are among important criteria in making an internationally recognized vibrant and livable country (NLP 2011). The introduction of NLP has stated:

"The National Landscape Policy (NLP) is a guide to steer the National landscape development, comprise of strategic policies and action plans as the catalyst for the National Development Policy. With the aim of becoming the Beautiful Garden Nation by 2020, NLP is expected to boost the country towards a total quality living environment, as well as accentuate Malaysia's unique landscape identity. This aspiration can be achieved through the preservation and conservation of natural resources, the implementation of planned development, as well as an effective National Landscape management system. The establishment of a conducive and balanced living environment will encourage socio-economic growth as well as the creation of an ethical and cultured society".

The role and rationale of the NLP are as follows:

"The National Landscape Policy (NLP) was formulated as an operational guide based on the approach of sustainable ecosystem. This policy will further enhance the sustainability of the Nation's development. The formulation of this policy takes into consideration existing policies and will complement and strengthen relevant policies. Thus, the scope and role of this policy is closely related to existing policies and sectors and will be adapted by current demand and local setting" (NLP 2011).

NLP rationale from the environmental aspect:

i. To protect and conserve natural resources, landscape assets and heritage that is unique with their own identities.

ii. To manage the development and preservation of the nation's landscape resources to be effectively implemented during planning and implementation through collaboration with various agencies.

iii. To create an efficient management system to sustainably conserve landscape natural resources and environment.

National Landscape Guideline is a reference for quality control in landscape project. The guideline covers all aspect of landscape development including detailed guidelines of tree planting works. About this research, the guideline will aid the objective of establishing the tree planting work assessment elements. In relation to exercising quality standard in construction, Standard and Industrial Research Institute of Malaysia (SIRIM) is a government-owned company under the Ministry of Finance; and SIRIM Berhad acts as the national organization of standardization and quality as well as the prime mover in industrial research and development, while bringing about national dynamism through excellence in technology and international acceptance of Malaysian products and services (SIRIM, retrieved online on December 1, 2016). 
As mentioned, SIRIM has established Landscape Standard which is MS 2603:2015 landscape planting materials-trees-specification. Landscape developments and work in Malaysia mainly executed based on National Landscape Policy and National Landscape Guideline from NLD, a specification from NPWD, landscape guideline from local authorities and independent specification produced by landscape companies for the specific project.

\subsection{Types of Organisation}

Organisation has three groups which are government, private and educational institution. In each of the group have own types of organization can be divided into five which are government agencies, developer, contractor, consultant and educational institution. Examples of the organization are Construction Industry Development Board Malaysia (CIDB), National Landscape Department (NLD), Standard and Industrial Research Institute of Malaysia (SIRIM), Malaysia Public Works Department (PWD) or Jabatan Kerja Raya (JKR) and local authorities are among the agencies under Malaysian government.

Institute of Landscape Architect Malaysia (ILAM), and landscape consultants are among the non-government agencies related to landscape development in Malaysia.

\subsection{Government agencies}

Government agencies can be divided into city council, municipal council, district council and policy maker. Basically, a local government or local authorities is responsible for managing the area especially for planning and maintenance. In Malaysia, total of city council is 13 numbers, municipal council is 39 numbers, and district council is 97 numbers. The policy maker are Construction Industry Development Board Malaysia (CIDB), National Landscape Department (NLD), Standard and Industrial Research Institute of Malaysia (SIRIM), Malaysia Public Works Department (PWD) or Jabatan Kerja Raya (JKR).

\subsubsection{The National Landscape Department (NLD)}

National Landscape Department has been established on 1st January 1996 under the patronage of Ministry of Housing and Local Government. The department was entrusted with monitoring landscape development from planning to maintenance to realised inspiration of turning Malaysia into 'Garden Nation' that conceived by the fourth Prime Minister, Tun Dr Mahathir Bin Mohamed in 1997. Furthermore, in addressing the issues of climate change, the department is committed to realising Malaysia's commitment protection and conservation of natural resources as declared in the Langkawi Declaration (1989), the Rio De Jenario Earth Summit (1992), and COP15 Change Conference 2009).

Through approval by Economic Planning Unit (EPU), National Landscape Department set a planning on landscape developments for the nation (NLD 2009). To reinforce planning and monitoring process of landscape development for the nation, NLD in 2008 has established a National Landscape Guideline second edition which is refined edition of the first National Landscape Guideline established by Landscape Unit under Federal Department of Town and Country Planning Peninsular Malaysia in 1995 (NLD, 2009 ).

The guideline covers all area of landscape planning and development of landscape for the nation. The guideline also covers implementation stage and maintenance stage of the landscape project. Some part of the guideline has been used as references for the development of specification of landscape construction e.g. Landscape Guideline for soft-scape in Section 4.

In the efforts to further ensure the realisation of Garden Nation, the government of Malaysia through National Landscape Department (NLD) has established National Landscape Policy in the year of 2011. In conjunction with the establishment of policy, Deputy Prime Minister of Malaysia, Tan Sri Dato' Mahyudin in his message highlighted that in the efforts to chart the development towards a high-income nation, quality landscape development and landscape natural resources protection are among important criteria in making an internationally recognized vibrant and livable country (NLP, 2011).

The role of the NLP is to be as an operational guide based on the approach of the sustainable ecosystem. The policy will further enhance the sustainability of the Nation's development. The formulation of the policy takes into consideration existing policies will complement and strengthen relevant policies. Thus, the scope and role of the policy is closely related to existing policies and sectors and will be adapted to demand and local setting (NLP, 2011).

\subsubsection{Standard and Industrial Research Institute of Malaysia (SIRIM)}

SIRIM is a premier industrial research and technology organisation in Malaysia, wholly-owned by the Ministry of Finance Incorporated. With over forty years of experience and expertise, SIRIM is mandated as the machinery for research and technology development, and the national champion of quality. SIRIM has always played a significant role in the development of the country's private sector. With its unique advantages in research and technology innovation, industry standards and quality, SIRIM offers specialised solutions to serve the needs of all industry sectors, making it the ideal technology partner for SMEs. By tapping into our expertise and knowledge base, we focus on developing new technologies and improvements in the manufacturing, technology and services sectors to enable businesses and enhance lives. Together with our industry partners, SIRIM has enabled Malaysian products and services achieve due recognition in quality and innovativeness worldwide. (SIRIM, retrieved online on December 1, 2016).

\subsection{Developer}

A property developer is a professional in the sector of property development, also known as real estate development. The property developer is developing an area or townships to create a positive legacy for communities to live well and thrive. The responsibilities of a property developer are numerous and may vary from one job to another. Some of the responsibilities of a property developer include 
purchasing land for new buildings, signing leases for existing properties, improving and renovating existing buildings and selling properties.

Some of the property developer in Malaysia listed are Eco World Development Group Berhad, Gamuda Land, IJM Land Berhad, IOI Properties Group Berhad, Mah Sing Group Berhad, Naza TTDI Sdn Bhd, S P Setia Berhad, Sunway Berhad, Tropicana Corporation Berhad, United Malayan Land Berhad (UMLand) and Sime Darby group.

\subsection{Contractor}

A contractor is a professional that undertakes a contract to provide materials or labor to perform a service or do a job. Related agencies with contractor are The Construction Industry Development Board Malaysia (CIDB) and Public Works Department (PWD).

\subsubsection{The Construction Industry Development Board Malaysia (CIDB)}

CIDB was established by Malaysian government on 1994 under Construction Industry Development Board Act (Act 520) to be as regulated body entrusted with responsibility of coordinating the need and wants of construction industry; planning the direction of the construction industry; addressing the pertinent issues and problems faced by the construction industry; and making recommendations in the formulation of policies for the construction Industry. CIDB (CIDB, retrieved online on December 1, 2016). Has outlined their roles about the construction industry in Malaysia as follows:

i. To promote and stimulate the development, improvement and expansion of the construction industry.

ii. To advise and make a recommendation to the government on matters related to the construction industry.

iii. To promote, stimulate and undertake research in matters relating to the construction industry.

iv. To promote, stimulate and assist in the export of service relating to the construction industry.

v. To provide consultancy and advisory services with respect to the construction industry.

vi. To promote quality assurance in the construction industry.

vii. To encourage the standardisation and improvement of construction techniques and materials.

viii. To initiate and maintain a construction industry information system.

ix. To provide, promote, review and coordinate training programs organised by public and private construction training centres for skilled construction workers and construction site supervisor.

$\mathrm{x}$. To accredit and register contractors including, to cancel, suspend or reinstate the registration of any registered contractors.

xi. To accredit and certify skilled construction workers and site.

\subsubsection{Public Works Department}

Malaysia Public Works Department (PWD) or Jabatan Kerja Raya (JKR) is a government department in Malaysia which constructs and maintains public infrastructure in Malaysia such as federal and state roads, government buildings and others. The agency is under the Malaysian Ministry of Works (MOW) (JKR, 2009). Some portions under the responsibility of PWD are landscape work. Therefore, PWD in their commitment to address the needs related to landscape work has established contract document with an inclusion of landscape standard specification. The specification has long been used or used as a reference by related parties in a construction project. Standard Specification related to soft-scape work stipulated under section N.4. (PWD, retrieved online on December 1, 2016).

\subsection{Landscape consultant}

The scope of works for Malaysian landscape architecture services are master planning, structure plan and local plan planning, sustainable landscape planning and design, environmental impact assessments (EIA) study, natural resources assessments, and landscape planning, design and consultancy. In landscape planning, design and consultancy been divided into twelve categories which are residential development, commercial development, offices and industrial development, riverbank, lake, seafront planning, pedestrian area and plazas, streetscapes planning and design, historical areas, ecological sensitive areas, revitalisation of abandoned lands, parks, theme parks, open spaces, neighborhood areas, tourism spots and resorts and golf course and club houses. (ILAM,2016)

Members' directory by Institute of Landscape Architects Malaysia (ILAM) session 2016/2017 the latest update on 10 October 2016 the total is to consultant been registered under ILAM directory.

\subsubsection{Institute of Landscape Architects Malaysia}

ILAM was originally known as Angkatan Landskap Malaysia (ALAM) established on 24th September 1981 and changed to Institute of Landscape Architects Malaysia (ILAM) on 14th December 1987. Transformation ALAM to ILAM also includes several amendments regulations on membership to ensure the higher level of professionalism in ILAM (ILAM, 2007). Since then ILAM has grown to 273 cooperate members (ILAM 2009).

Nationally, ILAM is recognised and become a member of Malaysia Professional Centre (MPC) or Balai lkhtisas Malaysia on 22nd April 1982 when it was still known as ALAM (ILAM 2013). The body is also internationally recognised through the acceptance to be a member of International Federation of Landscape Architects (IFLA) based in Versailles, France in 1984.

Membership of ILAM consists of several levels and cooperate member is in the highest rank of the membership where one should possess certain criteria and fulfil certain requirement set by ILAM for application to be a member. Among them, the person should possess a minimum Bachelor Degree qualification, minimum two years working experiences under the supervision of registered cooperate member and to attend a program conducted by ILAM known as Professional Practice for Landscape Architects and to sit 
and passed the special exam conducted once a year by ILAM. The process of qualification to be a member is to ensure a high level of professionalism of the members. (ILAM, retrieved online on December 1, 2016). (ILAM, 2016)

Members' directory by Institute of Landscape Architects Malaysia (ILAM) session 2016/2017 the latest update on 10 October 2016 the total is to consultant been registered under ILAM directory.

\subsection{Educational institution}

Basically, the institution for landscape architecture aims to train candidates to become landscape architects who are capable and skillful in all aspects of planning, designing and managing landscapes toward establishing a quality, healthy and balance environment for human needs. The programme is comprehensively designed so as to produce students who are well-versed in their fields of specialisation through multi-disciplinary courses. Landscape Architecture graduates are capable of facing current challenges in line with the Country's rapid development. They are sensitive and responsible in the utilisation of natural resources to meet the Country's development needs. Graduates from this programme have found jobs in multi-national consultancy firms overseas. Usually, This professional programme is accredited by the Malaysian Public Services Department (JPA) and the Institute of Landscape Architects Malaysia (ILAM).

In Malaysia there are several universities or colleague that offers the landscape architecture programme which are International Islamic University Malaysia (IIUM), Universiti Putra Malaysia (UPM), Universiti Teknologi Mara (UITM), Universiti Sains Malaysia (USM), Limkokwing University of Creative Technology, Geomatika Universiti College, and Infrastructure Universiti Kuala Lumpur (IUKL).

\subsection{Research Design}

This study which based on analysis of quantitative data collected. Quantitative method is used for identifying the relationship between types of organisation with the quality of soft-scape construction work in Malaysia. Three types of data collection techniques involved in this research, the literature review, analysis of document sources, and survey

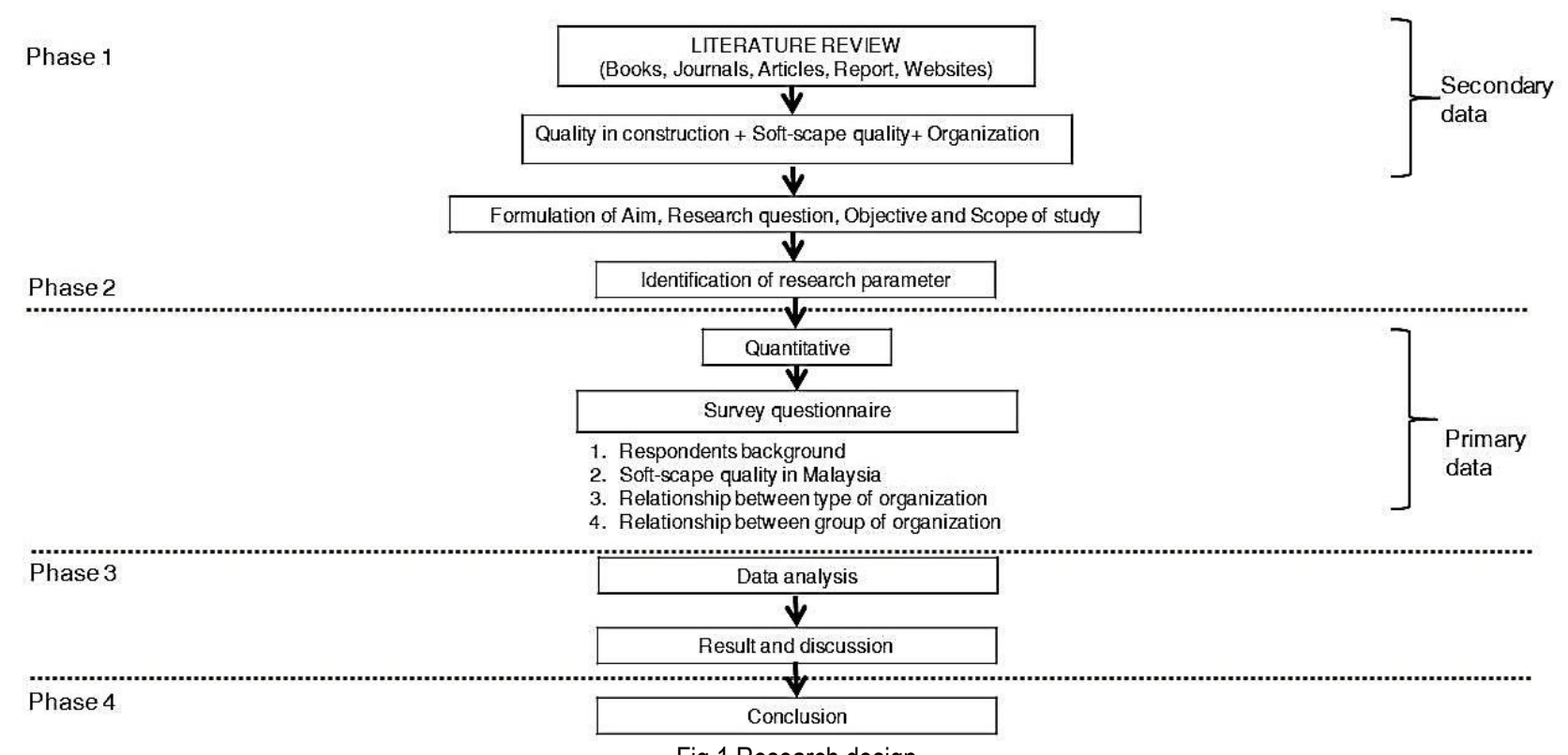

Fig 1 Research design

\subsection{Questionnaire}

The development of questionnaire was based on preliminary studies conducted. Secondary data collected are the basis of questionnaire development. The questionnaire was designed mainly to collect the data on experts' opinions on the critical level of the element in soft-scape construction. First section is questionnaire consists of the demographic background of the respondent. The next section consists of a set of question-related soft-scape quality in Malaysia and method quality control commonly used. The questionnaire consists of yes or no to be respond by respondents.

\subsection{Sampling Design}

Respondents of the survey are among Landscape Architects listed in ILAM directory 2008/209 from different organizations. There are 273 Landscape Architects listed in ILAM directory 2008/2009 (ILAM, 2009). The list of landscape architects in ILAM directory was arranged according to the sequence of membership number. The Respondents of the survey was selected alternately on the sequent of the list. The survey was started with landscape architect on number one in the list and followed by next number. In the case the researcher failed to reach any intended Landscape Architect, the selection was moved to the next person. The process continued until 
the last person. The researcher then continued the survey by started on the person that left unattended on the first round survey. The process of contacting and conducting survey continued until the last person on the list. In total, the study managed to conduct the survey on 225 persons.

\subsection{Data Analysis and Result}

The data analysis using the Statistical Packaging for Social Science SPSS version 14.0 was used to analyse data. Demographic distribution was analysed through descriptive analysis using SPSS version 14.0. The results have been tabled out to reveal the respondent demographic characteristic. Meanwhile, Chi-square analysis was also performed to find the significant level of relationship between the respondents from different types of organisations with their response to the open-ended questions on the issues of quality of soft-scape construction work.

\subsection{Demographic Characteristic}

The information on the socio-demographic character was gathered from Section A of the survey questionnaire. What the total number of respondents participated in the survey is 225 .

In the findings on the status of respondents, it is revealed that $53.8 \%$ of the total respondents were non-ILAM corporate members while $46.2 \%$ were ILAM corporate members. Distribution of respondents based on types of organisations showed that $47.6 \%$ of respondents were landscape consultants, followed by $22.7 \%$ serving in government agencies, $9.8 \%$ were contractor while the other $3.6 \%$ were developers and $16.4 \%$ from educational institutions. Regarding the organisation group, $60.9 \%$ of the respondents were from the private domain and $16.9 \%$ of the respondents come from the educational institutional and $22.2 \%$ were from government agencies. Refer Table 2.

\begin{tabular}{|c|c|c|c|}
\hline No. & Demographic Variables & $\mathrm{n}$ & $\%$ \\
\hline \multirow[t]{3}{*}{1} & Status & & \\
\hline & ILAM corporate Members & 104 & 46.2 \\
\hline & Non-ILAM corporate members & 121 & 53.8 \\
\hline \multirow[t]{6}{*}{2} & Types of organizations & & \\
\hline & Consultant & 107 & 47.6 \\
\hline & Contractor & 22 & 9.8 \\
\hline & Developer & 8 & 3.6 \\
\hline & Government agency & 51 & 22.7 \\
\hline & Educational institution & 37 & 16.4 \\
\hline \multirow[t]{4}{*}{3} & Groups of organizations & & \\
\hline & government & 50 & 22.2 \\
\hline & private & 137 & 60.9 \\
\hline & educational & 38 & 16.9 \\
\hline
\end{tabular}

\subsection{Soft-scape Quality in Malaysia}

$86.7 \%$ of the respondents claimed they had been involved in soft-scape construction work. However, the majority of the respondents pointed out that the quality of the soft scape-construction in Malaysia is not properly controlled. Most of the respondents had suggested that the soft scape construction in Malaysia necessitates room for improvement. $80 \%$ of the respondents, also, did not agree that the soft-scape construction work in this country had successfully complied with the specification requirement. Refer Table 3.

Table 3 Response on soft-scape quality in Malaysia

\begin{tabular}{|c|c|c|c|c|c|}
\hline \multirow{2}{*}{ No. } & \multirow{2}{*}{ Statements } & \multicolumn{2}{|c|}{ Yes } & \multicolumn{2}{|c|}{ No } \\
\hline & & n & $\%$ & n & $\%$ \\
\hline a & Involved in soft scape construction work & 195 & 86.7 & 30 & 13.3 \\
\hline$b$ & Thinks soft-scape Construction quality in Malaysia is well controlled & 42 & 18.7 & 183 & 81.3 \\
\hline
\end{tabular}


c Think quality soft-scape Construction in Malaysia need to be improved

Thinks soft-scape construction work in Malaysia successfully followed specification requirement
213

94.7

45

180

80

\subsection{Relationship between Types of organizations With the Issues of Quality of Soft-scape Construction Work}

The study seeks to investigate the relationship between respondents from different types of organisations with the issues of soft-scape construction quality. The study has provided a set of questions that consist of (A) Have you ever directly involved with soft-scape construction work?; (B) Do you think soft-scape construction quality in Malaysia is well controlled?; (C) Do you think soft-scape construction quality in Malaysia need to be improved?; and (D) Do you think soft-scape construction work in Malaysia successfully followed specification requirements?

Table 4 shows that respondents from different types of organisation $s$ have a significant influence on question $A$ and $C(p<0.05)$. The majority of respondents have directly involved with soft-scape construction work. With regards to the issues of soft-scape construction quality, the majority of respondents in the opinion that quality of soft-scape construction in Malaysia is not well controlled. The opinions may be influenced by their observation on the failure of soft-scape construction work to comply specification as shown in their response to question $\mathrm{D}$.

Table 4 Relationship between types of organizations with issues of quality of soft-scape construction work - Chi-square

\begin{tabular}{|c|c|c|c|c|c|}
\hline \multirow{2}{*}{ Questions } & \multicolumn{2}{|c|}{ Yes } & \multicolumn{2}{|c|}{ No } & \multirow{2}{*}{ Sig. } \\
\hline & $\mathrm{n}$ & $\%$ & $\mathbf{N}$ & $\%$ & \\
\hline \multicolumn{6}{|l|}{ Question A } \\
\hline Consultant & 96 & 89.7 & 11 & 10.3 & \multirow{5}{*}{.044} \\
\hline Contractor & 21 & 95.5 & 1 & 4.5 & \\
\hline Developer & 8 & 100.0 & & & \\
\hline Government agency & 43 & 84.3 & 8 & 15.7 & \\
\hline Educational institution & 27 & 73.0 & 10 & 27.0 & \\
\hline \multicolumn{6}{|l|}{ Question B } \\
\hline Consultant & 22 & 20.6 & 85 & 79.4 & \multirow{5}{*}{.547} \\
\hline Contractor & 6 & 27.3 & 16 & 72.7 & \\
\hline Developer & 1 & 12.5 & 7 & 87.5 & \\
\hline Government agency & 9 & 17.6 & 42 & 82.4 & \\
\hline Educational institution & 4 & 10.8 & 33 & 89.2 & \\
\hline \multicolumn{6}{|l|}{ Question C } \\
\hline Consultant & 103 & 96.3 & 4 & 3.7 & \multirow{5}{*}{.002} \\
\hline Contractor & 17 & 77.3 & 5 & 22.7 & \\
\hline Developer & 7 & 87.5 & 1 & 12.5 & \\
\hline Government agency & 51 & 100.0 & & & \\
\hline Educational institution & 35 & 94.6 & 2 & 5.4 & \\
\hline \multicolumn{6}{|l|}{ Question D } \\
\hline Consultant & 23 & 21.5 & 84 & 78.5 & \multirow{5}{*}{.513} \\
\hline Contractor & 7 & 31.8 & 15 & 68.2 & \\
\hline Developer & 1 & 12.5 & 7 & 87.5 & \\
\hline Government agency & 8 & 15.7 & 43 & 84.3 & \\
\hline Educational institution & 6 & 16.2 & 31 & 83.8 & \\
\hline
\end{tabular}




\subsection{Types of organization}

Arditi and Ongkasuwan (2009) cited in Jasasikin (2015) conducted research related to the perception of quality in construction and found that different people from the different organisation might have a different perception of the quality construction. These research findings show that types of organisations have a significant influence on perception toward certain critical success factor (CSF) of tree planting except for i.e. root ball size, soil mixture, and planting hole. Detailed analysis has revealed that consultant shows a significant mean difference in critical success factor (CSF) rating compared to a government agency and educational institution. Government agency and educational institution put more concern on root ball size as compared to the consultant.

Meanwhile, there is also a significant mean difference seen between contractor and government agency whereby respondents from government agency have put more concern on root ball and soil mixture as compared to respondents from construction companies. In overall, the findings can be concluded that contractor has less concern on soil mixture in planting work as compared to others.

The study also found that there is a significant different in consideration of critical level on planting hole from the government agency as compared to contractor and developer. Respondents from government agencies seem to put more concern on planting hole as compared to respondent from construction companies and developer.

\subsection{Conclusion}

This paper can be concluded the relationship between types of organisation with the quality of soft-scape construction work in Malaysia. The majority of the respondents claim that they are familiar with the process of quality control during construction on site. The research has found that majority of the respondents are in the opinion that soft-scape construction quality in Malaysia does not show up to satisfactory level and requires an improvement. The opinion of the quality level of soft-scape construction was deliberated from the low degree of conformance to the specification requirement. Also, the level of soft-scape quality also can be deliberated from the degree of rectification that needs to be done after the completion of work. In this research, the findings show that most of the projects have to undergo rectification work. About $80 \%$ respondents have claimed that more than $50 \%$ of the projects that they have involved need to undergo rectification work after completion. Most of the respondent from government agencies suggested that softscape construction quality in Malaysia need to be improved. Therefore, the future research on these areas should be done to improve the quality of soft-scape construction work in Malaysia.

\section{Acknowledgements}

The authors would like to thank the International Islamic University Malaysia for supporting this research under the Fundamental Research Grant Scheme (FRGS).

\section{References}

Arditi D. and Ongkasuwan D. (2009). Duties and Responsibilities of Construction Managers: Perceptions of Parties Involved in Construction. Journal of construction Engineering and Management. Vol. 135(12). (pp. 1370-1374)

Atkinson G. (1995). Construction Quality and Quality Standard: The European Perspective. E \& FN Spon.

CIDB (2016). CIDB Official Website. Retrieved on December 1, 2016 from http://www.cidb.gov.my

David W., Carl W. and Jean R. (2013). Soil Compaction. Colourado State University Extension (2013). CMG GardenNotes No. 215.

Garis Panduan Landskap Negara edisi 2 (GPLN 2) (2008). Jabatan Perancangan Bandar dan Desa. JPBD. Malaysia.

Hazreena H., Shahida S. and Ozanul E. O. (2013). Assessing Landscape Construction Course in Landscape Architectural Program. School of Landscape Architecture, Faculty of Built Environment, Kuala Lumpur Metropolitan University College.

Jasasikin A. S. (2015). Developing Quality Assessment Elements for Tree Planting Works. PhD Thesis. UniversityTeknologi Mara.

Jasasikin A. S. and Noriah O. (2011). Quality Standard and Specification for Soft-scape Construction in Malaysia. Asia Pacific International Conference on Environment-Behaviour Studies. Famagusta. North Cyprus. 7-9 December 2011.

Jasasikin A. S. and Noriah O. (2011). Soft-scape Construction Specification In Malaysia: Comparison Between Government And Private Sectors. International Conference on Management, Economics and Social Sciences (ICMESS'2011), Bangkok, Thailand. December 2011.

ILAM (2009). ILAMOfficial Website. Retrieved on December 1, 2016 from http://www.llamalaysia.org.

Malaysia Act 1996 :Act 549. (p. 8).

MS 2603:2015. (2015) Landscape Planting Materials-Trees-Specification, Malaysian Standard, Department of Malaysian Standard. Malaysia

NLD (2016). NLD Official Website. Retrieved on December 1, 2016 from http://jln.kpkt.gov.my/ 
NLP (2011). National Landscape Department. NLD. Malaysia.

Ofori G., G. Gang and C. Briffett (2002). Implementing Environmental Management Systems in Construction: Lessons from Quality Systems. Building and Environment. Vol. 37. (pp.1397-1407).

PWD (2016). PWD Official Website. Retrieved on December 1, 2016 from http://www.kkr.gov.my.

Roger W. (1996). The Professional Practice of Landscape Architecture: A Complete Guide to Starting And Running Your Own Firm. Van Nostrand Reinhold.

Sauter D. (2011). Landscape Construction. 3rd Edition. Cengage Learning.

SIRIM (2016). SIRIM Official Website. Retrieved on December 1, 2016 from http://www.sirim.my.

Spivak S. M., and Brenner F. C. (2001). Standardization Essential: Principles and Practice. Marcel Dekker, Inc. New York. 